JURNAL PENGABDIAN KEPADA MASYARAKAT

MAKARDHI

MANGANJALI KARYA WERDHI
Jurnal Pengabdian Kepada Masyarakat Makardhi

P-ISSN 2809-4174| E-ISSN 2808-084X

Vol. 1 No. 2 - Desember 2021

DOI: $10.52352 /$ makardhi.v1i2.589

Publisher: P3M Politeknik Pariwisata Bali

Available online: https://ejournal.ppb.ac.id/index.php/makardhi

\title{
Partisipasi Masyarakat Lokal Dalam Pengelolaan Desa Wisata Tenganan Pegringsingan di Kabupaten Karangasem
}

\author{
Anggun Dewi Roshinta*1, I Wayan Mertha' ${ }^{2}$, Hartanti Woro Susianti ${ }^{3}$ \\ 1,2,3 Program Studi Manajemen Kepariwisataan, Politeknik Pariwisata Bali \\ Jl. Dharmawangsa Kampial, Nusa Dua Bali, Nusa Dua Bali, Telp. (0361) 773537 \\ 1*shintaanggun1999@gmail.com, ${ }^{2}$ wayanmertha@ppb.ac.id, ${ }^{3}$ worosusianti@ppb.ac.id \\ *Penulis Korespondensi
}

\begin{tabular}{l|l|l}
\hline Received: Oktober, 2021 & Accepted: November, 2021 & Published: December, 2021 \\
\hline
\end{tabular}

\begin{abstract}
Tourism is a sector that gives huge contributions specifically the income to the economy for the goverment and people who live in Bali. Far from the pandemic of Covid-19, the central and the local governments were carrying out developments in the tourism sector which were implemented in the form of tourism villages. The development of a tourism village must be balanced with community participation which will greatly affect the progress of the tourism village itself, because the community plays a significant role as the host and the manager of the tourism village. This research aims to analyze the local community's participation and the factors that influence the local community's participation in managing the Tourism Village of Tenganan Pegringsingan in Karangasem Regency. The technique of collecting data was obtained through observation, survey, interview, documentation, and literature study. The research instrument was carried out by distributing questionnaires consisting of 16 indicators that is includes 5 (five) variables in the forms of participation. The sampling technique used was purposive sampling. Moreover, the data was obtained used descriptive qualitative analysis. The research results showed that the participation of strength had the highest average score of 3,64 which belongs to the category (often), and wealth participation had the lowest average score 2,50 belonging to the category (ever). The participation of the local community's in Tenganan Pegringsingan Village dominates the skills participation, however, was less enthusiastic in participating in ideas. Factors that influence the are dominated by people aged 26-35 with the male gender. For education, the people who dominated are the community at the high school level specifically by people who work as traders with an income level of Rp. 1.100.000 - Rp. 3.000.000. Moreover, it is dominated by people who have lived for 16-30 years.
\end{abstract}

Keywords : tourism village, community's participantion, tenganan pegringsingan village

\section{Abstrak}

Sektor pariwisata di Provinsi Bali merupakan penggerak utama sektor ekonomi yang menghasilkan pendapatan terbesar bagi pemerintah maupun masyarakat. Sebelum pandemi Covid-19, pemerintah pusat maupun daerah tengah melakukan pengembangan di sektor pariwisata yang diimplementasikan dalam bentuk desa wisata. Pengembangan desa 
Anggun Dewi Roshinta, I Wayan Mertha, Hartanti Woro Susianti

wisata harus diimbangi dengan partisipasi masyarakat yang akan sangat berpengaruh terhadap kemajuan desa wisata itu sendiri, karena masyarakat berperan sebagai tuan rumah dan pengelola desa wisata. Penelitian ini bertujuan untuk mengetahui bentuk partisipasi masyarakat dan faktor-faktor yang mempengaruhi partisipasi masyarakat lokal dalam pengelolaan Desa Wisata Tenganan Pegringsingan di Kabupaten Karangasem. Teknik pengumpulan data dilakukan dengan observasi, survei, wawancara, dokumentasi, dan studi literatur. Instrumen penelitian yang digunakan ialah kuisioner yang terdiri dari 16 indikator dari 5 (lima) variabel bentuk-bentuk partisipasi. Teknik penentuan sampel menggunakan purposive sampling. Kemudian, data yang diperoleh dianalisis dengan teknik analisis deskriptif kualitatif. Hasil penelitian menunjukkan bahwa partisipasi tenaga mendapatkan skor rata-rata tertinggi yaitu 3,64 termasuk kategori (sering) serta partisipasi harta benda mendapatkan skor terendah yaitu 2,50 termasuk kategori (pernah). Partisipasi masyarakat lokal Desa Tenganan Pegringsingan didominasi oleh partisipasi yang melibatkan tenaga namun kurang antusias dalam partisipasi yang melibatkan buah pikiran. Faktor-faktor yang mempengaruhi partisipasi didominasi oleh masyarakat berusia 26-35 tahun yang berjenis kelamin laki-laki. Untuk pendidikan didominasi oleh masyarakat setingkat SMA dengan pekerjaan sebagai pedagang dengan tingkat penghasilan Rp.1.100.000Rp.3.000.000. Serta didominasi oleh masyarakat Desa Tenganan Pegringsingan yang sudah tinggal selama 16-30 tahun.

Kata Kunci : desa wisata, partisipasi masyarakat, desa tenganan pegringsingan

\section{PENDAHULUAN}

Pariwisata merupakah salah satu sektor yang memberikan dampak yang sangat besar bagi pemerintah dan masyarakat lokal. Dimana pariwisata merupakan berbagai macam kegiatan wisata dan didukung berbagai fasilitas serta layanan yang disediakan oleh masyarakat, pengusaha, Pemerintah dan Pemerintah Daerah (UU No.10 tahun 2009). Dikarenakan adanya dampak yang sangat besar pada sektor pariwisata, hal tersebut menyebabkan sektor ini memiliki potensi menjadi pendorong utama perekonomian dan menjadi industri yang mendunia. Salah satu tujuan negara yang memiliki potensi pariwisata yang besar yaitu dengan meningkatkan jumlah wisatawan yang datang, maka pemerintah daerah melakukan banyak pengembangan di sektor pariwisata. Pengembangan pariwisata yang berhasil adalah pengembangan yang dilakukan secara bersama termasuk "membangun bersama masyarakat" sehingga pengembangan pariwisata dapat memberikan manfaat kepada masyarakat setempat. Saat ini model pengembangan pariwisata berbasis masyarakat banyak diimplementasikan dalam bentuk pengembangan desa wisata. Desa wisata dibentuk untuk memberdayakan masyarakat agar dapat berpartisipasi sebagai pelaku langsung dalam upaya meningkatkan kesiapan dan kepedulian dalam menyikapi potensi pariwisata atau lokasi daya tarik wisata di wilayah mereka agar dapat berperan sebagai tuan rumah yang baik bagi para wisatawan yang berkunjung, selain itu diharapkan pula agar masyarakat memiliki kesadaran akan peluang dan kesiapan menangkap manfaat yang dapat dikembangkan dari kegiatan pariwisata guna meningkatkan kesejahteraan ekonomi masyarakat (Nuryanti 1993 : 2-3). 
Anggun Dewi Roshinta, I Wayan Mertha, Hartanti Woro Susianti

Pengelolaan desa wisata tersebut harus diimbangi dengan adanya partisipasi bersama antara masyarakat. Dalam Ilmu Sosial, partisipasi masyarakat masuk kedalam intervensi komunitas. Pembangunan yang berbasis pada masyarakat ini harus menerapkan prinsip-prinsip desentralisasi, bersifat bottom up, mengikutsertakan masyarakat secara aktif, dan pembangunan harus dilaksanakan dari dan bersama masyarakat (Fadil, 2013). Peran masyarakat sebagai pelaku pembangunan bagi dirinya sendiri mampu menjadi faktor pendukung dalam pencapaian tujuan program pembangunan dari awal hingga akhir sehingga tercipta suatu pembangunan yang berkelanjutan. Pembangunan jenis ini telah dilakukan oleh pemerintah dalam berbagai bidang, salah satunya yaitu dalam bidang pariwisata (Dumasari \& Watemin, 2013).

Upaya pengembangan desa wisata menjadi salah satu alternatif dalam upaya peningkatan keterlibatan masyarakat atau partisipasi masyarakat dalam pengembangan sektor pariwisata di Kabupaten Karangasem, sesuai yang tertuang dalam SK Bupati Karangasem No. 658/HK/2014 tentang penetapan desa wisata. Jumlah desa wisata yang ada di Kabupaten Karangasem bisa dilihat pada tabel 1 sebagai berikut :

Tabel 1: Daftar Nama Desa Wisata di Kabupaten Karangasem

\begin{tabular}{lll}
\hline No. & Desa Wisata & Kecamatan \\
\hline 1. & Desa Pekraman Jasri & Karangasem \\
2. & Desa Budakeling & Bebandem \\
3. & Desa Timbrah & Karangasem \\
4. & Desa Tumbu & Karangasem \\
5. & Desa Tenganan & Manggis \\
6. & Desa Antiga & Manggis \\
7. & Desa Sibetan & Bebandem \\
8. & Desa Bugbug & Karangasem \\
9. & Desa Besakih & Rendang \\
10. & Desa Padang Bai & Manggis \\
11. & Desa Nongan & Rendang \\
12. & Desa Tanah Ampo & Manggis \\
13. & Desa Kastala & Bebandem \\
14. & Desa Duda & Selat \\
15. & Desa Pringsari & Selat \\
16. & Desa Jungutan & Bebandem \\
\hline
\end{tabular}

Sumber: Dinas Pariwisata Kabupaten Karangasem

Desa wisata yang ada di Kabupaten Karangasem sebagian besar memanfaatkan keindahan alamnya yang asri dan masih sangat terjaga. Setiap desa wisata memiliki ciri khasnya atau keunikannya masing-masing. Seperti Budaya Desa Tenganan Pegringsingan yaitu, adat-istiadatnya, upacara-upacara agama, bangunan-bangunan yang masih tradisional serta yang paling banyak menarik para wisatawan baik itu dalam maupun luar adalah atraksi Perang Pandan (Makare-karean) dan kerajinan tangan seperti kain Gringsing yang ditenun dengan teknik double ikat yang hanya bisa dibuat oleh masyarakat asli Desa Tenganan 
Anggun Dewi Roshinta, I Wayan Mertha, Hartanti Woro Susianti

Pegringsingan, anyeman ate serta gambaran diatas daun lontar. Desa Tenganan Pegringsingan merupakan salah satu Desa Wisata yang ada di Kabupaten Karangasem yang sudah dikenal di kancah Internasional. Hal ini tidak terlepas dari usaha dan kerjasama yang dilakukan oleh masyarakat lokal serta pengelola desa setempat untuk tetap menjaga citra yang telah dimiliki oleh Desa Tenganan Pegringsingan. Namun pandemi Covid-19 memberikan dampak besar terhadap sektor pariwisata yang ada di Provinsi Bali khususnya Kabupaten Karangasem dimana sektor pariwisata merupakan penghasil tertinggi pendapatan daerah yang menjadi pendapatan utama bagi pemerintah maupun masyarakat. Hal ini terlihat dari lesunya pergerakan perekonomian di Bali baik di perusahaan makro maupun mikro. Sehingga tingkat kunjungan wisatawan menurun sangat drastis tabel 2 sebagai berikut:

Tabel 2: Data Kunjungan Wisatawan ke Desa Tenganan Pegringsingan Tahun 2015 - 2020

\begin{tabular}{lllll}
\hline Tahun & \multicolumn{1}{c}{ Wisman } & \multicolumn{1}{c}{ Wisdom } & \multicolumn{1}{c}{ TOTAL } & \multicolumn{1}{c}{ Pertumbuhan } \\
\hline 2015 & 19.036 & 3.729 & 22.765 & $-45 \%$ \\
2016 & 38.491 & 8.528 & 47.019 & $107 \%$ \\
2017 & 27.526 & 5.395 & 32.921 & $-30 \%$ \\
2018 & 58.797 & 10.748 & 69.545 & $111 \%$ \\
2019 & 40.102 & 5.823 & 45.925 & $-34 \%$ \\
2020 & 4.441 & 2.922 & 7.363 & $-84 \%$
\end{tabular}

Sumber: Dinas Pariwisata Provinsi Bali, 2021

Kesadaran akan pariwisata telah dirasakan oleh masyarakat Desa Tenganan Pegringsingan. Hal ini berdampak kepada para pengurus desa yang pada akhirnya bergerak untuk mengelola tempat yang tersedia menjadi lebih baik untuk digunakan masyarakat lokal desa menjual hasil kerajinannya. Dimana terlihat di bagian depan Desa Adat Tenganan Pegringsingan terdapat banyak kios cinderamata yang didirikan oleh desa. Selain mendirikan kios, terdapat tempat parkir yang luas untuk parkir kendaraan wisatawan yang berkunjung serta fasilitas pelengkap lainnya seperti kamar kecil dan tempat cuci tangan yang memadai. Bagi masyarakat lokal dapat dilihat dari banyaknya penenun kain Gringsing yang memajang dan menjual kepada wisatawan yang datang ke desa tersebut. Tentu dalam hal ini dibutuhkan pengelolaan yang tepat agar peningkatan pariwisata di Desa Tenganan tidak hanya menjual kain tenun Gringsing namun dapat memberikan pengalaman baru dan memberikan kenangan khusus yang dapat dirasakan oleh wisatawan yang datang berkunjung. Pengalaman tersebut tercipta dari partisipasi masyarakat lokal itu sendiri yang diberikan kepada wisatawan.

Pengembangan desa wisata di Desa Tenganan Pegringsingan berkontribusi besar bagi masyarakat lokal khususnya bagi masyarakat pelaku usaha wisata, karena dengan pengembangan desa wisata di Desa Tenganan Pegringsingan banyak para wisatawan baik itu dalam maupun luar negeri yang berkunjung ke sana dan tentunya hal ini akan memberi pengaruh besar bagi para pelaku usaha 
Anggun Dewi Roshinta, I Wayan Mertha, Hartanti Woro Susianti

wisata. Dengan banyaknya wisatawan yang datang berkunjung maka semakin besar pula penghasilan yang akan didapat oleh pelaku usaha wisata di Desa Tenganan Pegringsingan sehingga dapat mensejahterakan masyarakat pelaku usaha wisata. Oleh karena itu, kesadaran dari masyarakat lokal perlu terus ditumbuhkan dan ditingkatkan sehingga nantinya partisipasi akan dirasakan sebagai suatu kewajiban yang harus dilakukan. Berdasarkan uraian tersebut maka mahasiswa/i meneliti secara mendalam partisipasi masyarakat lokal dalam pengelolaan Desa Wisata Tenganan Pegringsingan di Kabupaten Karangasem. Penelitian ini dimaksudkan untuk mengetahui bentuk partisipasi masyarakat lokal dalam pengelolaan Desa Wisata Tenganan Pegringsingan dan faktor-faktor yang mempengaruhi partisipasi masyarakat lokal terhadap pengelolaan Desa Wisata Tenganan Pegringsingan.

\section{METODE PENELITIAN}

Metode analisis data yang digunakan pada penelitian ini adalah analisis statistik deskriptif yaitu statistik yang digunakan dalam menganalisis data dengan cara mendeskripsikan atau menggambarkan data yang telah terkumpul. Objek dalam penelitian ini adalah bentuk partisipasi dan faktor-faktor yang mempengaruhi masyarakat lokal dalam pengelolaan Desa Wisata Tenganan Pegringsingan. Data yang dikumpulkan diperoleh melalui observasi, wawancara, kuesioner dan dokumentasi. Teknik pengambilan sample yang digunakan adalah Purposive Sampling, dengan kriteria yaitu sampel yang dipilih minimal berumur 17 tahun, mengetahui tentang desa, memahami populasi atau masyarakat dan memiliki peran di dalam Desa Adat Pegringsingan. Jumlah sample dalam penelitian ini adalah sebanyak 90 responden yang diserahkan kepada masyarakat lokal.

\section{HASIL DAN PEMBAHASAN \\ Uji Validitas Hasil Penelitian}

Untuk mencari validitas sebuah item dengan cara mengkorelasikan skor item dengan total item-item tersebut. Jika koefisien antara item dengan total item sama atau di atas 0,361 ( $\mathrm{r}$ tabel $\geq \mathrm{r}$ hitung) maka item tersebut dikatakan valid, tetapi jika nilai korelasinya dibawah 0,361 ( $\mathrm{r}$ tabel $<\mathrm{r}$ hitung ) maka item tersebut ditanyakan tidak valid. Pengujian validitas diambil dari 30 hasil kuisioner yang disebarkan kepada 30 responden. Setelah berhasil diuji dengan hasil setiap pernyataan valid atau $r$ hitung $\geq r$ tabel maka kuisioner dapat digunakan dan dilanjutkan untuk disebar kembali hingga mendapatkan jumlah sampel yang dibutuhkan yaitu 90 responden. Berdasarkan hasil olah data pada SPSS dapat disimpulkan bahwa seluruh indikator dimasing-masing variabel dinyatakan valid. Karena hasil setiap pernyataan memiliki nilai $r$ hitung lebih besar dari $r$ tabel $(r$ hitung $>0,361$ ). 


\section{Uji Reliabilitas Hasil Penelitian}

Uji reliabilitas harus dilakukan hanya pada pernyataan atau indikator yang telah memenuhi uji validitas dengan kata lain uji reliabilitas dilakukan setelah menguji instrumen pada kuisioner dengan uji validitas. Kriteria suatu instrumen penelitian dikatakan konsisten atau reliabel bila koefisien reliabilitas > 0,6. Berdasarkan hasil olah data pada SPSS dapat dapat dijelaskan bahwa nilai Alpha Cronbach's disetiap variabel yang digunakan dalam penelitian ini $\alpha>0,6$. Dalam hal ini disimpulkan bahwa seluruh instrumen dalam penelitian ini telah reliabel.

\section{Karakteristik Responden}

Adapun jumlah sampel pada penelitian ini adalah 90 responden. Persentase jenis kelamin untuk profil responden didominasi oleh laki-laki dengan persentase sebesar 55,6\% yang dibandingkan dengan persentase pada perempuan yakni 44,4\%. Berdasarkan usia didominasi pada rentang usia 26-35 tahun dengan jumlah responden terbanyak yaitu 32 orang dengan persentase 35,6\%. Tingkat pendidikan terakhir dari responden yang telah mengisi kuesioner ini didominasi oleh tingkat SMA sebanyak 41 orang dengan persentase $45,5 \%$.

Sebagian besar responden memiliki jenis pekerjaan sebagai pedagang dengan persentase 46,7\%. Berdasarkan data yang diperoleh masyarakat lokal Desa Tenganan Pegringsingan yang menjadi memiliki tingkat penghasilan sebesar Rp. 1.100.000 - Rp. 3.000.000 dilihat dari jumlah responden terbanyak yaitu 58 orang dengan persentase 64,4\%. Sedangkan untuk lama tinggal masyarakat lokal Desa Tenganan Pegringsingan yang menjadi responden sudah tinggal di desa selama 1630 tahun dilihat dari jumlah responden terbanyak yaitu 42 orang dengan persentase $46,7 \%$. Sebagian besar responden memiliki peran sebagai pengarajin seni dilihat dari jumlah responden terbanyak yaitu 56 orang dengan persentase $62,2 \%$. Hal ini dikarenakan masyarakat membuat cinderamata khas Desa Tenganan Pegringsingan seperti kain tenun gringsing, lukisan didaun lontar, telur hias dan pengrajin rotan yang

\section{Bentuk Partisipasi Masyarakat Lokal Dalam Pengelolaan Desa Wisata Tenganan Pegringsingan di Kabupaten Karangasem}

Partisipasi masyarakat dalam pengelolaan Desa Wisata Tenganan Pegringsingan memiliki bentuk-bentuk partisipasi yang dilaksanakan oleh masyarakat lokal. Bentuk partisipasi secara teori terdiri dari 5 (lima) bentuk partisipasi seperti teori yang disampaikan Huraerah (2008:102) yang terdiri dari partisipasi buah pikiran, partisipasi tenaga, partisipasi harta benda, partisipasi kemahiran dan keterampilan, serta partisipasi sosial. Kelima bentuk partisipasi masyarakat menurut teori tersebut telah dilaksanakan oleh masyarakat lokal Desa Wisata Tenganan Pegringsingan yang ikut serta dalam pengelolaan desa. Dalam 
mencari skor rata-rata dari kelima bentuk partisipasi tersebut, kuisioner yang telah disusun disebarkan kepada responden yang dituju kemudian responden dapat memilih atau menjawab lebih dari satu indikator. Adapun skor rata-rata dari bentuk partisipasi yang telah dilakukan oleh masyarakat lokal di Desa Wisata Tenganan Pegringsingan dapat dilihat pada gambar 1. berikut

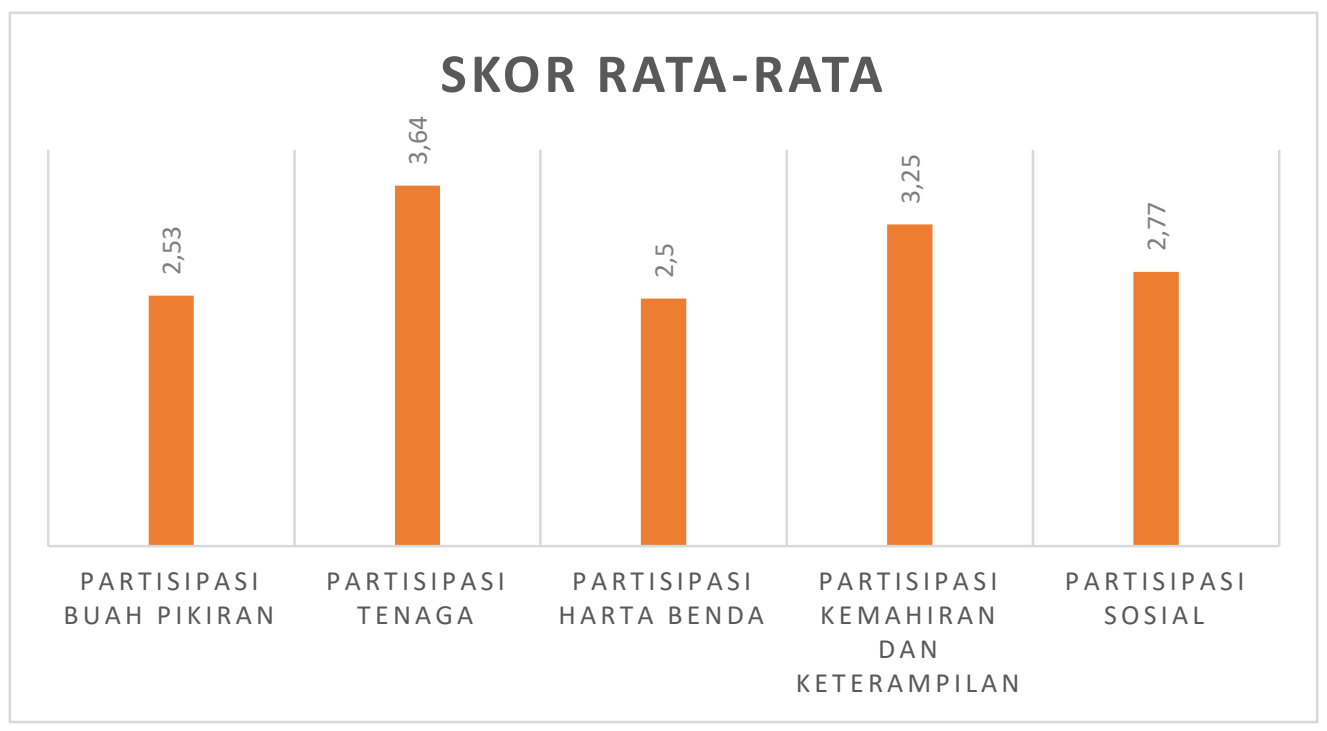

Gambar 1 : Bentuk Partisipasi Masyarakat Lokal Dalam Pengelolaan Desa Wisata Tenganan Pegringsingan

Berdasarkan pada Gambar 4.1 dapat dilihat bahwa terdapat 5 (lima) bentuk partisipasi yang telah dilaksanakan oleh masyarakat lokal Desa Wisata Tenganan Pegringsingan. Bentuk partisipasi menurut teori tersebut terdiri dari: partisipasi buah pikiran, partisipasi tenaga, partisipasi harta benda, partisipasi kemahiran dan keterampilan serta partisipasi soial. Kelima bentuk partisipasi tersebut akan di jabarkan sebagai berikut:

\section{a. Partisipasi Buah Pikiran Masyarakat Lokal}

Berdasarkan hasil olah data kuesioner didapat hasil yakni skor rata-rata dari bentuk partisipasi buah pikiran yang telah dilakukan masyarakat lokal Desa Tenganan Pegringsingan sebesar 2,53 yang termasuk kategori Pernah (P). Hal ini dikarenakan sebagian masyarakat lokal Desa Tenganan Pegringsingan pernah mengikuti rapat desa tentang pengembangan desa, bentuk pengelolaan desa, rapat tentang keputusan untuk menjalankan tradisi perang pandan, pernah mengikuti sosialisasi dan pemahaman tentang pariwisata yang di dampingi oleh dinas pariwisata Kabupaten Karangasem, mengikuti sosialisasi mengenai CHSE di era new normal yang di dampingi pula oleh dinas pariwisata Kabupaten Karangasem, serta masyarakat selalu terlibat dalam pengambilan keputusan dalam pembentukan pengelolaan demi kemajuan Desa Wisata Tenganan Pegringsingan. Partisipasi buah pikiran yang dilakukan oleh 
Anggun Dewi Roshinta, I Wayan Mertha, Hartanti Woro Susianti

masyarakat lokal Desa Wisata Tenganan Pegringsingan yaitu berupa menyumbangkan ide-ide atau gagasan yang berkaitan dengan pengelolaan desa. Partisipasi buah pikiran juga ditunjukkan dengan memberikan saran yang berkaitan untuk menunjang kegiatan pengelolaan Desa Wisata Tenganan Pegringsingan

\section{b. Partisipasi Tenaga Masyarakat Lokal}

Dari hasil olah data kuesioner diperoleh hasil bahwa skor rata-rata dari bentuk partisipasi tenaga yang telah dilakukan masyarakat lokal Desa Tenganan Pegringsingan sebesar 3,64 yang termasuk kategori Sering (S). Hal ini dikarenakan masyarakat lokal Desa Tenganan Pegringsingan sering melakukan kegiatan kerja bakti untuk membersihkan lingkungan desa maupun sekitarnya yang dilakukan rutin setiap bulan. Partisipasi tenaga yang dilakukan oleh masyarakat lokal di Desa Wisata Tenganan Pegringsingan berupa terlibat dalam berbagai kegiatan untuk pengelolaan desa. Partisipasi tenaga lainnya masyarakat lokal terlibat dalam kegiatan kerja bakti yang rutin dilaksanakan tiap bulan maupun pembangunan fasilitas desa untuk menunjang aktivitas pariwisata serta kenyamanan masyarakat selama berada di desa. Partisipasi tenaga masyarakat lokal juga ditunjukkan dalam kegiatan pemeliharaan fasilitas dan prasarana untuk menunjang aktivitas desa.

\section{c. Partisipasi Harta Benda Masyarakat Lokal}

Berdasarkan hasil olah data kuesioner diperoleh hasil yakni skor rata-rata dari bentuk partisipasi harta benda yang telah dilakukan masyarakat lokal Desa Tenganan Pegringsingan sebesar 2,50 yang termasuk dalam kategori Pernah (P). Hal ini dikarenakan masyarakat lokal Desa Tenganan Pegringsingan berpartisipasi dalam bentuk materi dengan membayar iuran kebersihan serta untuk mendukung berbagai kegiatan pengelolaan desa. Partisipasi harta benda yang dilakukan oleh masyarakat lokal Desa Tenganan Pegringsingan yaitu ikut serta berpartisipasi dalam bentuk materi untuk mendukung berbagai kegiatan pengelolaan Desa Tenganan Pegringsingan. Partisipasi harta benda lainnya berupa masyarakat ikut serta memberikan iuran kebersihan kepada pihak pengelola Desa Tenganan Pegringsingan. Serta dalam bentuk partisipasi harta benda masyarakat memberikan sumbangan berupa materi untuk mendukung kegiatan adat di Desa Tenganan Pegringsingan.

\section{d. Partisipasi Kemahiran dan Keterampilan Masyarakat Lokal}

Diperoleh hasil skor rata-rata dari bentuk partisipasi kemahiran dan keterampilan yang telah dilakukan masyarakat lokal Desa Tenganan Pegringsingan sebesar 3,25 yang termasuk dalam kategori Cukup Sering (CS). Hal ini dikarenakan masyarakat lokal Desa Tenganan Pegringsingan berpartisipasi dalam bentuk kemahiran dan keterampilan dengan membuat berbagai macam kerajinan berupa telur hias, kerajinan rotan, lukisan lontar, dan kain khas Desa Tenganan yaitu kain tenun gringsing dengan teknik double 
ikat yang hanya dapat dibuat oleh masyarakat asli Desa Tenganan Pegringsingan. Partisipasi kemahiran dan keterampilan yang dilakukan oleh masyarakat Desa Tenganan Pegringsingan berupa ikut terlibat sebagai pemandu wisata di desa. Kemudian partisipasi kemahiran dan keterampilan yang dilakukan masyarakat ikut terlibat dalam penyedia kegiatan industri seperti: pembuatan cinderamata hias telur, kerajinan rotan, lukisan lontar, dan kain tenun gringsing. Lalu partisipasi lain yang dilakukan masyarakat ikut terlibat dalam pembuatan tuak aren. Serta masyarakat lokal Desa Tenganan Pegringsingan ikut terlibat dalam tradisi perang pandan yang selalu diadakan tiap tahun.

\section{e. Partisipasi Sosial Masyarakat Lokal}

Dari hasil olah data kuesioner diperoleh hasil bahwa skor rata-rata dari bentuk partisipasi sosial yang telah dilakukan masyarakat lokal Desa Tenganan Pegringsingan sebesar 2,77 yang termasuk dalam kategori Cukup Sering (CS). Hal ini dikarenakan masyarakat lokal Desa Tenganan Pegringsingan berpartisipasi dalam bentuk sosial dengan masyarakat berperan aktif dalam keikutsertaannya kepada berbagai organisasi yang ada di desa guna membentuk pengelolaan desa lebih baik dan lebih maju. Partisipasi sosial yang dilakukan oleh masyarakat lokal Desa Tenganan Pegringsingan ialah ikut terlibat dalam organisasi badan pengelola desa yang bertanggung jawab dalam pengelolaan desa di Desa Tenganan Pegringsingan. Kemudian partisipasi sosial yang dilakukan oleh masyarakat lokal golongan muda atau menengah yaitu ikut terlibat dalam organisasi STT Desa Tenganan Pegringsingan. Serta partisipasi sosial yang dilakukan oleh masyarakat lokal yang didominasi oleh remaja perempuan dan ibu-ibu ialah ikut terlibat dalam organisasi PKK yang ada di Desa Tenganan Pegringsingan.

Masyarakat lokal Desa Tenganan Pegringsingan lebih menonjol dalam partisipasi tenaga atau kerja fisik seperti: kegiatan kerja bakti, pembangunan fasilitas desa dengan skor rata-rata 4,16, kegiatan pemeliharaan fasilitas dan prasarana untuk menunjang kegiatan desa dengan skor rata-rata 4,14, ikut terlibat dalam kegiatan perang pandan dengan skor rata-rata 4,17, serta ikut terlibat dalam penyedia kegiatan industri dengan skor rata-rata 3,74. Namun sebaliknya, masyarakat lokal Desa Tenganan Pegringsingan dalam bentuk partisipasi untuk pengelolaan desa cenderung kurang antusias dilihat dari hasil rata-rata skor yang rendah seperti bentuk partisipasi tenaga untuk ikut terlibat dalam berbagai kegiatan untuk pengelolaan desa dengan skor rata-rata 2,63, dalam bentuk partisipasi sosial untuk ikut terlibat dalam organisasi badan pengelola desa dengan skor rata-rata 2,40, dalam bentuk partisipasi harta benda untuk memberikan sumbangan berupa materi guna mendukung berbagai kegiatan pengelolaan desa dengan skor rata-rata 2,28, serta bentuk partisipasi buah pikiran berupa ide dan gagasan terkait pengelolaan desa dengan skor rata-rata 2,01. 


\section{Faktor-faktor yang dapat mempengaruhi Partisipasi Masyarakat Lokal Dalam Pengelolaan Desa Wisata Tenganan Pegringsingan di Kabupaten Karangasem}

Berdasarkan hasil penelitian dan pengamatan yang telah dilakukan kelima faktor yakni usia, jenis kelamin, pendidikan, pekerjaan dan penghasilan serta lama tinggal tersebut dapat mempengaruhi masyarakat lokal untuk ikut berpartisipasi dalam mengelola Desa Wisata Tenganan Pegringsingan. Untuk usia masyarakat lokal yang mendominasi aktif untuk berpartisipasi ialah berusia 26-35 tahun dengan persentase sebesar 35,6\%. Dikarenakan dalam usia tersebut lebih sering mengikuti kegiatan yang ada di desa seperti gotong royong, rapat, diskusi, maupun berkecimpung di dalam organisasi.

Kemudian faktor jenis kelamin masyarakat lokal yang aktif untuk berpartisipasi ialah laki-laki dengan persentase sebesar 55,6\%. Dikarenakan lakilaki memiliki peluang lebih besar untuk berpartisipasi terhadap desa seperti menjadi perangkat desa dan wajib mengikuti tradisi perang pandan. Lalu untuk faktor tingkat pendidikan yang mempengaruhi masyarakat lokal Desa Tenganan Pegringsingan untuk berpartisipasi didominasi oleh masyarakat yang berpendidikan tingkat SMA/SMK dengan persentase sebesar 45,6\%. Dalam hal ini dapat mempengaruhi pola pikir masyarakat sehingga kurang antusias dalam mengmukakan ide dan gagasan mengenai pengelolaan desa.

Untuk faktor pekerjaan dan penghasilan didominasi oleh masyarakat yang berpartisipasi dengan bekerja sebagai pedagang dengan persentase sebesar 46,7\%. Dalam hal ini masyarakat menjual berbagai macam cinderamata yang mejadi ciri khas Desa Tenganan Pegringsingan. Secara tidak langsung dapat mempromosikan dan menarik minat kunjungan wisatawan nusantara maupun mancanegara untuk datang ke Desa Tenganan Pegringsingan. Dan masyarakat lokal dengan tingkat penghasilan berkisar antara Rp. 1.100.000-Rp. 3.000.000 dengan persentase sebesar 64,4\%. Dengan penghasilan menengah tersebut masyarakat dapat berpartisipasi dalam bentuk harta benda dengan membayar iuran dalam pengelolaan desa dan iuran kebersihan guna menjaga kebersihan di dalam desa yang dapat memberi kenyamanan kepada wisatawan maupun masyarakat yang berada di desa itu sendiri. Selain itu, dapat membangun berbagai fasilitas desa maupun pariwisata serta merawat fasilitas tersebut guna memberikan kenyamanan kepada wisatawan yang datang untuk berkunjung ke Desa Tenganan Pegringsingan.

Serta faktor lamanya tinggal masyarakat lokal berada di Desa Tenganan Pegringsingan dapat mempengaruhi untuk ikut berpartisipasi didominasi oleh masyarakat yang sudah tinggal selama 16-30 tahun dengan persentase sebesar 46,7\%. Hal ini disebabkan semakin lamanya tinggal seseorang di lingkungannya dapat menimbulkan rasa kenyamanan dan kepemilikannya. Sehingga secara tidak 
Anggun Dewi Roshinta, I Wayan Mertha, Hartanti Woro Susianti

langsung masyarakat tersebut ikut serta untuk berpartisipasi dalam bentuk apapun untuk mengelola desa yang menjadi tempat tinggal mereka.

Kelima bentuk partisipasi dan kelima faktor yang telah dijabarkan di atas dapat memberikan pengaruh kepada masyarakat untuk ikut aktif berpartisipasi terhadap Desa Tenganan Pegringsingan. Bentuk partisipasi dan faktor yang mempengaruhi dalam berpartisipasi merupakan satu keterkaitan yang tidak bisa dipisahkan. Karena ketika mengetahui bentuk partisipasi yang telah dilakukan masyarakat dapat pula mengetahui faktor apa saja yang mempengaruhi masyarakat untuk berpartisipasi dalam mengelola Desa Tenganan Pegringsingan. Sehingga perlu adanya peningkatan Sumber Daya Manusia (SDM) guna mengelola dan menjalankan kontribusi Desa Tenganan Pegringsingan menjadi lebih tertata, dapat mensejahterakan masyarakat dan meningkatkan pariwisata secara berkelanjutan.

\section{KESIMPULAN}

Berdasarkan pada pembahasan sebelumnya, maka hal tersebut dapat disimpulkan sebagai berikut :

1. Skor rata-rata dari kelima bentuk partisipasi partisipasi didominasi oleh bentuk partisipasi tenaga dengan skor tertinggi yaitu 3,64 (72,8\%). Masyarakat antusias dalam berpartisipasi tenaga dengan melakukan kegiatan gotong royong atau kerja bakti, membangun fasilitas serta merawat prasarana pariwisata yang ada di desa. Bentuk partisipasi lainnya, partisipasi kemahiran dan keterampilan dengan skor 3,25 (65\%), partisipasi sosial dengan skor 2,77 $(55,4 \%)$, partisipasi buah pikiran dengan skor 2,53 (50,6\%). Serta skor terendah yaitu bentuk partisipasi harta benda sebesar 2,50 (50\%). Dalam hal ini masyarakat membayar iuran yang ada di desa guna mengelola dan menjalankan kontribusi desa. Namun tidak melulu dibayarkan oleh materi dapat digantikan dengan tenaga dengan melakukan kegiatan kerja bakti maupun gotong royong.

2. Sebagian besar masyarakat Desa Tenganan Pegringsingan yang berpartisipasi didominasi oleh masyarakat laki-laki $(55,6 \%)$ berusia $26-35$ tahun $(35,6 \%)$. Dalam hal tersebut dapat memberikan pengaruh untuk berpartisipasi dengan mengikuti kegiatan desa seperti kerja bakti, membangun fasilitas desa, rapat, diskusi, sosialisasi maupun menjadi anggota organisasi yang ada di desa. Pendidikan masyarakat didominasi se-tingkat SMA/SMK (45,6\%). Dalam hal ini masyarakat kurang memahami sistem pengelolaan dan kurangnya pengetahuan sehingga kurang antusias untuk memberikan ide atau gagasan terkait pengelolaan desa. Masyarakat bekerja sebagai pedagang $(46,7 \%)$. Hal ini mempengaruhi masyarakat melakukan hal seperti membuat cinderamata, menenun kain gringsing, menjadi pemandu wisata yang secara tidak langsung dapat menarik minat wisatawan untuk berkunjung. Serta penghasilan masyarakat berkisar Rp1.100.000-Rp.3.000.000 (64,4\%). Hal ini mempengaruhi 
masyarakat untuk membayar iuran guna mengelola dan menjalankan kontribusi desa. Dan Desa Tenganan didominasi oleh masyarakat yang sudah tinggal selama 16-30 tahun (46,7\%). Hal ini dapat mempengaruhi masyarakat untuk berpartisipasi dalam bentuk apapun dikarenakan tumbuhnya rasa kepemilikan serta tanggung jawab untuk tetap menjaga lingkungannya.

\section{PERNYATAAN PENGHARGAAN}

Dalam penelitian ini penulis menyampaikan terimakasih kepada seluruh narasumber yang telah bersedia meluangkan waktu dan memberikan informasi yang dibutuhkan. Penulis juga berterimakasih yang sebesar-besarnya kepada kedua dosen pembimbing yang telah menyediakan waktu untuk mengoreksi dan memberikan saran dalam penelitian ini. Tak lupa juga penulis mengucapkan terimakasih kepada kedua orang tua, keluarga serta sahabat yang telah mendukung secara moral maupun materi.

\section{DAFTAR PUSTAKA}

A.J, Muljadi. 2012. Kepariwisataan dan Perjalanan. Jakarta: Raja Grafindo Persada. HIm 12

Anonimus, 2001. Peraturan Daerah Propinsi Bali Tahun 2001 tentang Desa Adat, Denpasar. Sekretariat Daerah Propinsi Bali.

Anthonius, Ibori. 2013. Partisipasi Masyarakat Dalam Pelaksanaan Pembangunan Di Desa Tembuni Distrik Tembuni Kabupaten Teluk Bintuni. Jurnal

Burnss et al. 2004. Making Community Participation Meaningful. UK : The Policy Press.

Dumasari, \& Watemin. 2013. Karakteristik Sosial Ekonomi Petani Miskin dalam Pengelolaan Usaha Mikro “Tourism Souvenir Goods." Mimbar, 29(2), 205-214. Emzir. 2012. Metodologi Penelitian Pendidikan Kuantitatif dan Kualitatif. Bandung: Rajagrafindo Persada.

Ghozali, Imam. Aplikasi Analisis Multivariate Dengan Program IBM SPSS19", Edisi 5. Semarang : Badan Penerbit Universitas Diponegoro,2011.

Gumelar S. Sastrayuda. 2010. Konsep Pengembangan Kawasan Desa Wisata. Jurnal Hadiwijoyo, Surya Sakti. 2013. Perencanaan Pariwisata Perdesaan Berbasis Masyarakat (Sebuah Pendekatan Konsep). Jurnal. HIm 15

Huraerah, Abu. 2008. Pengorganisasian Dan Pengembangan Masyarakat: Model Dan Strategi Pembangunan. Bandung: Alfabeta.

Ismayanti. 2013. Pengantar Pariwisata. Jakarta: Grasindo. Hlm 51

Kriska, Mesalia dkk. 2019. Partisipasi masyarakat dalam community based tourism di desa wisata puton watu ngelak kabupaten bantul. Yogyakarta: Universitas Gadjah Mada.

Laksana, Nuring Septyasa. 2008. Bentuk-Bentuk Partisipasi Masyarakat Desa Dalam Program Desa Siaga di Desa Bandung Kecamatan Playen Kabupaten 
Anggun Dewi Roshinta, I Wayan Mertha, Hartanti Woro Susianti

Gunung Kidul Provinsi Daerah Istimewa Yogyakarta. Surabaya. Universitas Airlangga. Jurnal. Vol. 1, No. 1, pp 60-61

Mahadewi, Eka. 2015. Metode Penelitian Pariwisata Dari Konsep ke Implementasi. Bali: STP Nusa Dua Bali.

Nurwahab, Muhamad. 2017. Partisipasi Masyarakat Ciburial Dalam Pengembangan Desa Wisata Di Kabupaten Bandung. Bandung. Universitas Pendidikan Indonesia.

Pratama, Utama Dewa. 2015. Pengaruh Sektor Pariwisata Terhadap Penyerapan Tenaga Kerja di Kabupaten Lombok Barat. Malang. Universitas Brawijaya.

Priasukmana Soetarso dan R. Mohamad Mulyadin. 2013. Pembangunan Desa

Wisata : Pelaksanaan Undang-undang Otonomi Daerah. Jurnal. hlm 38

Sanjaya, Rindo Bagus. 2018. Strategi Pengembangan Pariwisata Berbasis

Masyarakat di Desa Kemetul, Kabupaten Semarang. Semarang. Universitas Kristen Satya Wacana.

Siregar, Syofian. 2017. Metode Penelitian Kuantitatif. Jakarta : Kencana Prenada Media Group.

Sugiyono. 2009. Metode penelitian Bisnis (Pendekatan Kuantitatif, Kualitatif dan R\&D). Bandung: Alfabeta.

Suriana. 2009. Analisis Keberlanjutan Pengelolaan Sumber Daya Laut Guguspulau Kaledupa Berbasis Partisipasi Masyarakat. Thesis Program Magister Ekonomi dan Manajemen. Bogor: Institut Pertanian Bogor.

Tiodora, Hendriani Saputri. 2019. Partisipasi Masyarakat Lokal Dalam Pengelolaan Daya Tarik Wisata Riam Palayo di Kabupaten Bengkayang. Badung. Sekolah Tinggi Pariwisata Nusa Dua Bali.

Undang-Undang No. 10 Tahun 2009 Tentang Kepariwisataan. 